論文

자체-센서와 미세 작동기를 위한 CNT/PVDF 및 ITO/PVDF 나노복합재료의 전기적 및
계면 내구성 비교 평가

구가영*, 왕작가, 권동준, 박종만 ${ }^{*+}$

\title{
Interfacial Durability and Electrical Properties of CNT or ITO/PVDF Nanocomposites for Self-Sensor and Micro Actuator
}

Ga-Young Gu* ${ }^{*}$ Zuo-Jia Wang ${ }^{*}$, Dong-Jun Kwon*, Joung-Man Park ${ }^{*+}$

\begin{abstract}
Interfacial durability and electrical properties of CNT or ITO coated PVDF nanocomposites were investigated for self-sensor and micro actuator applications. Electrical resistivity of nanocomposites for the durability on interfacial adhesion was measured using four points method via fatigue test under cyclic loading. CNT/PVDF nanocomposite exhibited lower electrical resistivity and good self-sensing performance due to inherent electrical property. Durability on the interfacial adhesion was good for both CNT and ITO/PVDF nanocomposites. With static contact angle measurement, surface energy, work of adhesion, and spreading coefficient between either CNT or ITO and PVDF were obtained to verify the correlation with interfacial adhesion durability. The optimum actuation performance of CNT or ITO coated PVDF specimen was measured by the displacement change using laser displacement sensor with changing frequency and voltage. The displacement of actuated nanocomposites decreased with increasing frequency, whereas the displacement increased with voltage increment. Due to nanostructure and inherent electrical properties, CNT/PVDF nanocomposite exhibited better performance as self-sensor and micro actuator than ITO/PVDF case.
\end{abstract}

\section{초 록}

자체-센서와 미세 작동기 응용을 위한 $\mathrm{CNT}$ 와 ITO로 코팅된 나노복합재료의 계면접착 내구성과 전기적 특성을 평가하였 다. 나노복합재료의 접착 및 계면 내구성은 반복하중 피로시험에 따른 전기저항도를 측정하여 평가하였다. CNT와 ITO의 고 유 전기적 특성으로 인하여 CNT가 코팅된 PVDF 나노복합재료는 ITO가 코팅된 경우보다 다소 낮은 전기저항도를 나타내었 으나, 모두 양호한 자체-감지능을 보여주었다. CNT/PVDF와 ITO/PVDF 나노복합재료 모두 계면 내구성은 양호함을 확인하였 다. 정적 접촉각 시험을 통해 $\mathrm{CNT}$ 와 ITO 그리고 $\mathrm{PVDF}$ 간의 표면에너지, 접착일, 그리고 퍼짐계수를 평가하여 계면 내구성과 의 상호 관련성을 확인하였다. 수용액에서 $\mathrm{CNT}$ 와 ITO로 코팅된 PVDF 시편의 최적의 작동성은 주파수와 전압을 달리하여 레이져 변위센서를 사용한 연신율 변화로 측정하였다. 작동된 두 나노복합재료들의 연신율은 주파수가 증가함에 따라 감소하 며, 반면에 전압의 증가에 따라 상승하였다. 각 나노복합재료의 나노구조 및 고유의 전기적 특성으로 인하여, CNT/PVDF가 $\mathrm{ITO} / \mathrm{PVDF}$ 보다 자체-감지 및 작동기로서 더 적합하다는 것을 알 수 있었다.

Key Words : 작동기(actuator), 감지(sensing), 내구성(durability), 젖음성(wettability)

접수: 2011년 6월 24일, 수정: 2011년 10월 14일, 게재승인: 2011년 11월 22일

* 경상대학교 나노.신소재공학부 대학원

*+ 경상대학교 나노.신소재공학부, 공학연구원, 교신저자(E-mail:jmpark@gnu.ac.kr) 


\section{1. 서 론}

나노복합재료의 작동기의 대표적인 예로서 전기활성고분자 (electroactive polymer)의 일종인 이온성 고분자-금속 복합재료 (ionic polymer metal composites, IPMC)은 최근 몇 년간 작동 기 구성 물질로서 새롭게 부상하고 있는 재료이다. 전기활성 고분자는 크게 IPMC, 전도성 고분자(conducting polymer), 겔 (gel), 그리고 전기변형 고분자(electrostrictive polymer)의 네 가 지로 나눌 수 있다. 이 중 전도성 고분자는 고분자의 산화/환 원 시에 부피의 변화를 수반하는데 이러한 부피의 변화를 엑 츄에이터의 구동원리로 이용하고 있다. IPMC는 고분자막의 양 표면에 금속 전극을 형성한 후에 전계를 인가하면 막 내부에 서 이온의 이동에 의한 부피의 변화가 일어나며 결과적으로 전계의 방향에 따라 인장 압축되어 구동되는 작동기이다.

앞에서 설명한 전도성 고분자 작동기와 $\mathrm{IPMC}$ 는 기존의 작동기에 비해 저전압 구동이 가능하고 동작 시 열이나 전자 기파 등을 발생하지 않으며 이러한 성질을 이용하여 인공근육 의 제작 또는 팔다리의 동작을 모방하는데 이용된다[1]. 복합 재료의 작동과 감지특성은 고유의 전도성과 절연성에 강하게 의존한다[2]. 그리고 $\mathrm{IPMC}$ 는 젖은 상태에서 전기적 자극을 받 아서 작동을 하기 때문에 기계적, 전기적, 화학적 성질이 결합 된 상당히 복잡한 작동 특성을 가진 재료이다. 현재 IPMC의 기계적, 전기적, 화학적 특성과 IPMC 모델링에 관한 많은 연 구가 진행되고 있다[3]. 전기활성고분자(electroactive polymer) 의 일종인 이온성 고분자-금속 복합재료 전도성 물질을 코팅한 나노복합재료는 센서와 작동기로서 사용된다. 본 연구에서 사 용된 PVDF (poly(vinylidene fluoride))는 압전능을 가진 고분자 로서 센서와 작동기 재료로 사용될 수 있는 스마트 재료로 연 구 되고 있다[4]. 탄소나노튜브 (CNT)의 출현은 CNT의 물리 적 기계적 특성에 관해 연구되며, 발전가능성 있는 과학기술의 응용에 연구된다. 나노튜브는 높은 단단함과 강도를 갖추고 있 으며, 이는 이론적, 실험적으로 모두 확인되었다[5]. CNT 역시 굉장히 높은 전기적, 열전도성을 가진다[6].

또한, 작동기는 복합재료로써 활용된다. 복합재료의 물성 은 계면 접착력이 중요하다. 계면 접착력은 강화재와 기지재 물질 간의 계면에 존재하는, 산-염기 결합에 기여하는 많은 반응기들에 의존한다. 섬유 표면에 대한 산-염기 결합은 주 어진 기지재 물질이 함유한 계면접착강도를 조절하기 위한 중요한 요인이다. 그러므로, 기지재가 가진 산-염기 결합을 사전에 알게 된다면 강화재와 기지재간의 최적 조합을 가능 하게 할 수 있다. 산-염기 결합 조성의 평가는 동적 접촉각 측정을 통해 가능하다[7,8].

본 연구에서는 CNT 나노복합재료와 ITO 나노복합재료의 전기적 특성을 반복하중 시험하는 동안 전기저항도를 측정하 여 알아보았으며, 계면 특성을 각 재료의 표면 젖음성 시험을 이용하여 접촉각을 측정하여 평가하였고 또한, CNT와 ITO 나노복합재료의 작동기가 스마트 소재로서의 성능을 평가하기
위해 연구하였다. 이러한 작동기는 전기화학적 환경에서 작동 된 연신율을 레이저변위센서로 측정 함으로써 작동기의 특성 최적 조건을 찾고, 주파수와 전압, $\mathrm{CNT}$ 와 $\mathrm{ITO}$ 의 함량에 따른 작동 연신율을 평가하였다. CNT 나노복합재료와 ITO 나노복 합재료의 전기적 특성, 계면 특성 그리고 작동기의 특성을 평 가하여 어느 복합재료가 더욱 작동기로 적합한지 평가하였다.

\section{2. 실 험}

\section{1 재료}

다중벽 카본탄소튜브 (MWCNT, 일진나노텍)와 인듐틴옥 사이드 (ITO, 미지텍)가 작동기를 제작하는데 사용되었다. 코 팅공정에서 CNT와 ITO 용액을 제조하기 위하여, CNT의 분 산 용매로 아세톤과 ITO의 분산용매로 에탄올을 사용하였다. 모재로 폴리비닐리덴플루오라이드 (poly(vinylidene fluoride), PVDF, Aldrich)를 다이메틸포름아마이드 (dimethylformamide, $\mathrm{DMF}$ )에 용해하여 사용하였다.

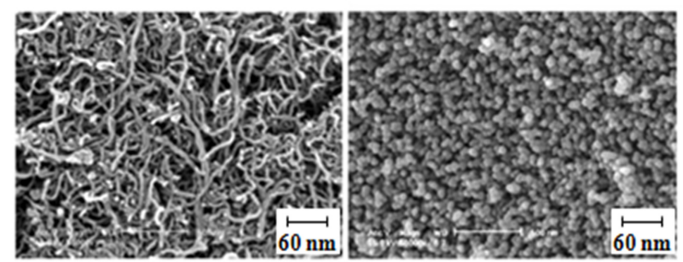

(a)

(b)

Fig. 1 SEM photos of mophology of the surface (a) CNT; and (b) ITO powder.

Fig. 1는 작동기 시편에 사용된 CNT와 ITO 소재의 상호 다른 표면형태를 보여준다. 형상비가 큰 $\mathrm{CNT}$ 는 서로 상호 엉켜있는 모양이며, 이에 비해 구 형상의 ITO는 분말 상태 로 상호 결착되어 있는 형태이다.

\subsection{CNT와 ITO 코팅된 복합재료 시편제조}

Fig. 2은 CNT와 ITO 코팅 된 복합재료의 제조공정을 보 여준다. $\mathrm{CNT}$ 와 $\mathrm{ITO}$ 는 비이커에서 12 시간 동안 초음파 (sonication)처리를 통하여 다이메틸포름아마이드와 에탄올에 분산되었다. 분산된 $\mathrm{CNT}$ 와 $\mathrm{ITO}$ 용액은 샬레에 부어 $60^{\circ} \mathrm{C}$ 오 븐에서 용매를 증발시켰다. 용매가 증발된 CNT와 ITO 시트 위에 $70^{\circ} \mathrm{C}$ 오븐 안에서 4 시간 동안 $\mathrm{DMF}$ 에 용해된 $\mathrm{PVDF}$ 를 부어 다시 한번 $60^{\circ} \mathrm{C}$ 오븐에서 용매를 제거하였다. 이렇게 제조된 CNT-PVDF와 ITO-PVDF 나노복합재료가 작동기 시 편으로 만들어졌다. 나노복합재료의 CNT와 ITO 함량은 10 $\mathrm{wt} \%$ 로 각각 제작되었다. 제조 한 나노복합재료의 크기는 길 이 $35 \mathrm{~mm}$, 폭 $5 \mathrm{~mm}$, 두께 $0.08 \mathrm{~mm}$ 이다. ITO와 $\mathrm{CNT}$ 층의 두께는 $0.02 \mathrm{~mm}$ 이며 PVDF 층의 두께는 $0.06 \mathrm{~mm}$ 이다. 


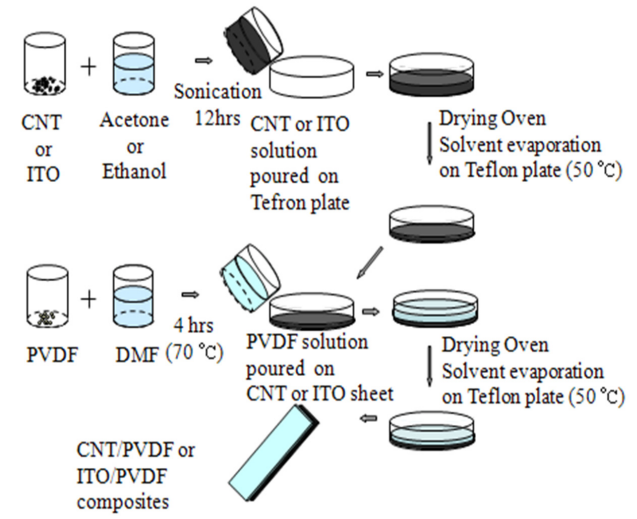

Fig. 2 Preparation process of CNT-PVDF and ITO-PVDF sheet.

\section{3 특성평가 방법}

\subsection{1. 반복하중의 전기적 특성측정}

$\mathrm{CNT}$ 및 ITO 나노복합재료의 전기저항은 4점 탐침법을 사용하여 측정하였다. 표면저항은 단일배열법과 비교하여, 이 중 배열법은 모서리 영향을 제거하게 되어 전체 측정거리에 서 균일한 전기저항을 구할 수 있다. 표면저항 측정은 일열 로 배열된 4 개의 탐침을 사용하여 측정한다. 측정 방법은 두 가지가 있으며, 첫째, 단일배열법은 일 열로 나란히 배열된 4 개의 탐침 중 두 개의 바깥쪽 두 개의 탐침에 전류를 흐르 게 하고 안쪽 두 개의 탐침에서 전압을 측정을 하는 방법이 다. 둘째, 이중 배열법은 단일배열법의 방법과 함께 첫 번째 와 세 번째 탐침에 전류를 흐르게 하고, 나머지 탐침에서의 전압을 측정하여 아래의 식에 의해 저항을 측정하는 방법 이 다. 이중 배열법에 대한 식은 식 (1), (2)와 같다.

$$
\begin{aligned}
& R_{s}=k_{a} \times R_{a} \\
& k_{a}=-14.696+25.173\left(\frac{R_{a}}{R_{b}}\right)-7.872\left(\frac{R_{a}}{R_{b}}\right)^{2}
\end{aligned}
$$

여기서, $R s$ 는 이중 배열법으로 측정되는 저항값이며, $R a$ 는 단일배열 법으로 측정되는 저항값, $R b$ 는 두 번째 방법으로 측정된 저항값이다.

\subsection{2. 젖음성 측정}

젖음성 측정방법인 동적 및 정적 접촉각 측정 중에서 본 연 구에서는 정적 접촉각으로 측정하였다. $\mathrm{CNT}$, ITO, 그리고 $\mathrm{PVDF}$ 에 측정 용매들의 작고 균일한 드롭을 떨어뜨려 액체와 소재간에 이루어 지는 정적인 접촉각은 광학현미경 사진을 이 용하여 각을 직접 측정하였다. 사용된 측정 용매로는 이중증류 수, 포름아마이드, 에틸렌글리콜, 다이오도메탄 네가지 용매를 사용하였다. 정적 접촉각은 Young에 의해 식 (3)으로 표시된다.
$\gamma_{S}-\gamma_{S L}=\gamma_{L} \cos \theta$

여기서, $\gamma_{L}$ 는 액체의 표면장력, $\gamma_{S L}$ 는 고체/액체간의 계면 에너지, 그리고 $\gamma_{s}$ 는 고체의 표면에너지이다[9]. 전체 표면장 력, $\gamma_{T}$ 은 Lifshits-van der Waals 조성, $\gamma_{L W}$ 와 산-염기 조성, $\gamma$ ${ }_{A B}$ 의 합이다. 산-염기 조성 (혹은 수소결합)은 전자받기, $\gamma^{+}$와 전자주기, $\gamma$ 조성을 포함한다. 또한, 접착일, $W_{a}$ 을 나타내는 변형된 Young-Dupre 식은 다음과 같다.

$$
W_{a}=\gamma_{L}(1+\cos \theta)=2\left(\gamma_{L}^{L W} \gamma_{S}^{L W}\right)^{\frac{1}{2}}+2\left[\left(\gamma_{S}^{-} \gamma_{L}{ }^{+}\right)^{\frac{1}{2}}+\left(\gamma_{S}{ }^{+} \gamma_{L}{ }^{-}\right)^{\frac{1}{2}}\right]
$$

고체의 $\gamma_{s}^{L W}$ 은 전자받기와 전자주기가 없는 비극성 용액의 접촉각으로부터 구해진다. 극성과 분산표면에너지를 구하기 위해, Owens-Wendt 식은 다음과 같이 나타낸다.

$$
W_{a}=\gamma_{L}(1+\cos \theta)=2\left(\gamma_{S}{ }^{d} \gamma_{L}{ }^{d}\right)^{\frac{1}{2}}+2\left(\gamma_{S}{ }^{p} \gamma_{L}{ }^{p}\right)^{\frac{1}{2}}
$$

고체와 액체간의 퍼짐 정도를 나타내는 식은 다음과 같이 나타내며 퍼짐계수 (Spread coefficient), $S$ 로 나타낸다.

$$
S=2\left[\left(\gamma_{L} \gamma_{S}\right)^{1 / 2}-\gamma_{L}\right]
$$

\subsection{3 전기화학적 환경에서의 작동기 실험}

Fig. 3 은 전기화학적 환경에서 작동기의 전체적인 실험장치 를 보여준다. 그림 $3(\mathrm{a})$ 는 전체적인 작동기 실험장치를 확인하 였으며, 그림 3(b)는 그림 3(a)에서 시편이 있는 부분으로 시편 의 설치 모양과 그리고 연신율 측정 방법만의 확대된 부분이다.

전기화학적 환경에서 사용된 기기는 임의 파형발생기 (FG-7002C, EZ), 전압공급기 (GP-4503DU, EZ)로부터 전압을 공급받는 레이저변위센서 (LK-2000 Series, Keyence, Japan), 멀티미터 (34401A, HP), 데이터수집장치 (Agilent 34972A $\mathrm{LXI}$ ), 산도/전도도 측정기 (Cyberscan PC6000, Eutech)가 사 용되었다. 작동기 실험은 임의파형발생기로 주파수와 전압을 공급하였으며, 작동된 연신율은 레이저변위센서로 시편의 연 신율을 측정함으로써 계산되며, 실험 중 변화되는 전류와 다 른 전기적 데이터는 데이터 수집장치로 조사하였다.

Fig. 4는 전기화학적 환경에서 작동기의 개념도를 나타낸 다. 화학적 반응은 전기도금 원리와 비슷하다. 이는 음극에서 환원반응으로 전자와 구리이온, 수소이온이 반응하여 구리와 수소가스가 배출되며, 양극에서는 산화반응이 일어나 구리가 전자를 내놓으면서 이온화된다. 구동하는 원리는 전압을 공 급함으로서 내부 전자이동으로 인한 작동이 발생한다. 전자 의 이동으로 한쪽 면은 전자가 편중 되어 시편이 팽창하는 반면 다른 면은 전자가 부족하게 되어 시편 수축으로작동기 가 움직이는 것을 확인하였다.

작동기의 변위는 레이저 변위센서로 측정가능 하며 변위에 


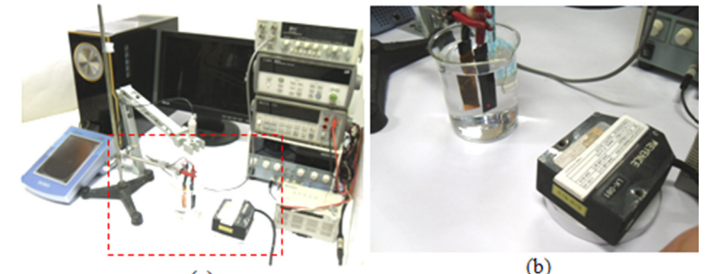

(a)

(b)

Fig. 3 Experimental scheme of electrochemical actuator in electrolyte solution using laser displacement sensor: (a) whole; (b) magnified region.

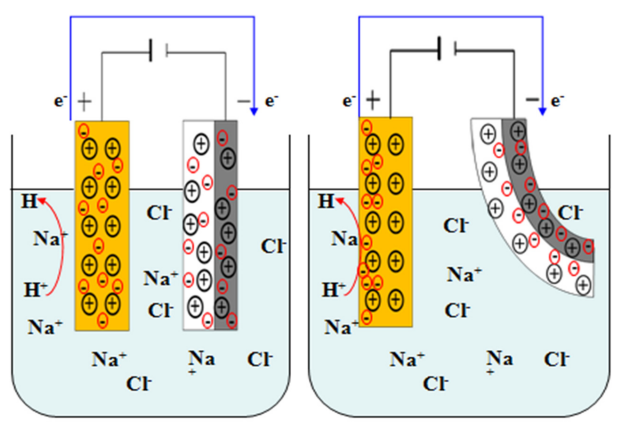

Fig. 4 Scheme of actuator processing in electrochemical field

대한 식은 식 (7)로써 나타낼 수 있다. 이 변위를 시편의 길 이와 두께에 따른 연신율로 나타낼 수 있 는데 이는 식 (8) 로써 표현할 수 있다.

$$
\begin{aligned}
& \delta=\frac{P L^{3}}{3 E I} \\
& \varepsilon=\frac{3 y(L-x)}{L^{3}} \delta
\end{aligned}
$$

여기서 $\delta$ 는 작동기의 변위를 나타내며, $P$ 는 힘을 나타내 고 $L$ 은 시편의 총 길이, $E$ 는 Young의 모듈러스, $I$ 는 안쪽으 로 굽는 정도를 나타낸다. $\varepsilon$ 은 작동기의 연신율을 나타내며 $y$ 는 시편 두께, $\chi$ 는 변위측정 지점을 나타낸다.

\section{3. 결과 및 토론}

\section{1 반복하중하에서의 저항도 감지능}

Fig. 5는 반복하중에 따른 $\mathrm{CNT/PVDF}$ 와 ITO/PVDF 나노 복합재료의 표면저항도 변화를 통한 (a) 감지능과(b) 피로 시 험을 통한 내구성을 각각 보여 준다. Fig. 5(a)는 부가된 초 기 5 회 반복 하중에 대한 전기적 감지도로 두 나노 소재가 모두 잘 감지하는 것을 볼 수 있다. 하지만, 고유 전기적 특 성차이로 인해, $\mathrm{CNT} / \mathrm{PVDF}$ 의 표면 저항도는 $10 \mathrm{M} / / \mathrm{sq}$ 로 32 $\mathrm{M} / / \mathrm{sq}$ 인 ITO/PVDF에 비하여 낮았다. Fig. 5(b)에서는 두 나노
Table 1 Acid-base and polar-dispersion surface energy component and comparison of work of adhesion, $W_{a}$ and spreading coefficient, $\mathrm{S}\left(\mathrm{mJ} / \mathrm{m}^{2}\right)$

\begin{tabular}{c:ccccccc:cc}
\hline Type & $\gamma_{\mathrm{s}}^{\mathrm{T}}$ & $\gamma_{\mathrm{s}}^{\mathrm{LW}}$ & $\gamma_{\mathrm{s}}^{\mathrm{AB}}$ & $\gamma_{\mathrm{s}}^{+}$ & $\gamma_{\mathrm{s}}^{-}$ & $\gamma^{\mathrm{d}}$ & $\gamma^{\mathrm{p}}$ & $\boldsymbol{W}_{\boldsymbol{a}}$ & $\boldsymbol{S}$ \\
\hline \hline PVDF & 32.2 & 31.7 & 0.6 & 0.0 & 3.9 & 27.7 & 2.9 & - & - \\
\hdashline CNT & 56.3 & 22.5 & 33.8 & 19.9 & 14.4 & 74.7 & 13.0 & 27.5 & 20.8 \\
ITO & 49.6 & 41.8 & 7.9 & 0.4 & 43.4 & 26.0 & 30.2 & 8.4 & 15.6 \\
\hline
\end{tabular}
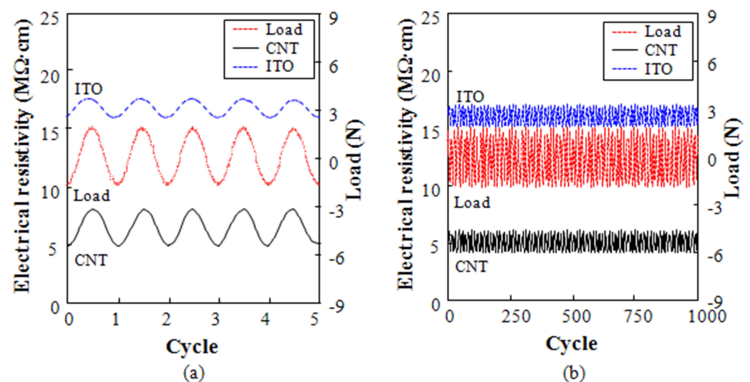

Fig. 5 Electrical resistivity of ITO-PVDF and CNT-PVDF layers by (a) sensing; and (b) fatigue tests

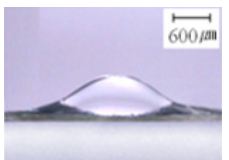

(a)

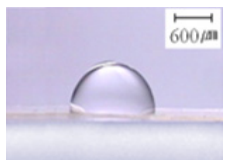

(b)

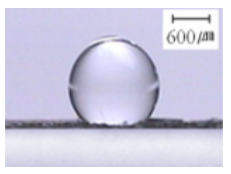

(c)
Fig. 6 Optical photos of static contact angle of actuator material with double distilled water droplet; (a) neat PVDF; (b) CNT/PVDF; and (c) ITO/PVDF sheets

복합재료 모두 1,000 회전의 반복하중에서도 전기저항도가 대 체로 일정하게 유지되었다. 이는 CNT와 ITO 모두가 최적의 시편제조 조건으로 인하여, PVDF와 계면접착력에 대한 내구 성이 양호하기 때문이다. 즉, 작동기 시편을 만드는 과정 중, CNT와 ITO 시트 위에 PVDF 용액에서 용매 제거 과정동안 $\mathrm{PVDF}$ 와 두 $\mathrm{CNT}$ 와 $\mathrm{ITO}$ 가 접착이 잘 되었기 때문이다.

\section{2 젖음성과 표면 에너지와의 상관관계}

Fig. 6은 나노복합재료의 모재인 $\mathrm{PVDF}$ 와 CNT와 ITO가 함침된 $\mathrm{PVDF}$ 표면에서의 물에 대한 각각의 정적 접촉각을 보여준다. $\mathrm{PVDF}$ 의 정적 접촉각은 소수성인 89 도이며, 이에 비해 CNT는 초 소수성인 134도를 나타내었다. 또한, ITO는 $\mathrm{PVDF}$ 나 CNT보다 상대 적으로 훨씬 적은 35 도로 친수성을 보여주었다. 각 $\mathrm{CNT}$ 와 ITO간의 접촉각이 크게 다르다는 것 은 이 재료들의 표면특성 및 나노구조 형상이 다르기 때문이 다. 따라서, 두 재료간의 계면접착 상태도 달라지며, 이는 나 노복합재료의 내구성에 큰 영향을 끼친다.

Table 1은 4 가지 용매를 각각 사용하여 앞의 식 (3), (4)를 이용하여 $\mathrm{PVDF}, \mathrm{CNT}$, ITO의 표면에너지를 구한 것이 며, 산- 


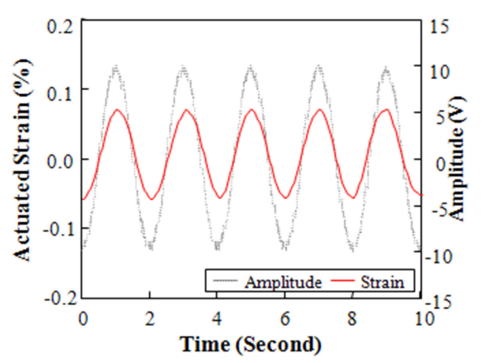

(a)

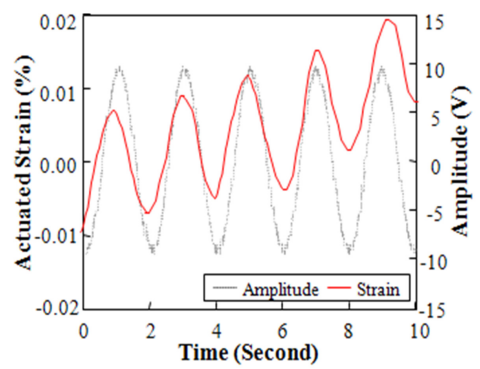

(b)

Fig. 7 Actuated strain versus amplitude curve for different actuator: (a) CNT-PVDF and (b) ITO-PVDF layer.

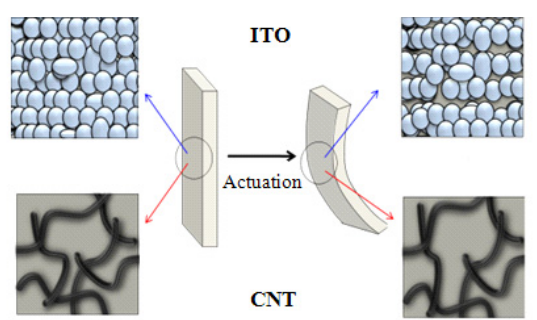

Fig. 8 Scheme of the change in actuator surface morphology after actuation.

염기 상호작용과 극성-분산 표면에너지 조 성과 접착일과 퍼 짐계수 (Spreading Coefficient)를 나타내었다. 표면에너지 조성 으로 식 (5)를 이용하여 재료간의 접착일과 식 (6)을 이용하여 퍼짐계수, $\mathrm{S}$ 를 구하였다. CNT와 $\mathrm{PVDF}$ 간의 접착일이 크고 퍼 짐계수 역시 상대적으로 높으며, 반면에 ITO와 PVDF간의 접 착일은 작고 퍼짐계수는 $\mathrm{CNT}$ 보다 낮은 값을 보여주었다. 접 착일은 완전히 접착이 된 두 물질을 때어낼 때 필요한 열역학 적인 힘으로서, 실제로는 미세역학시험 등을 통하여 계면접착 강도를 확인할 수 있다. 또한, 퍼짐계수는 퍼짐일 (work of Spreading)을 나타내는 정도로서, 퍼짐일은 고체와 액체가 분 리될 때 (퍼짐의 반대 과정) 발생하는 자유에너지 변화로 정 의한다. 이는 자유에너지가 낮아질수록 반응은 자발적으로 변 한다. 즉, 자유에너지가 낮아질수록 자유에너지의 변화는 점차 증가하여 자발적 퍼짐을 가진다. 증가된 퍼짐계수를 통해 젖 음성이 높아진다는 것을 의미한다. 젖음성이 높아질 때에는
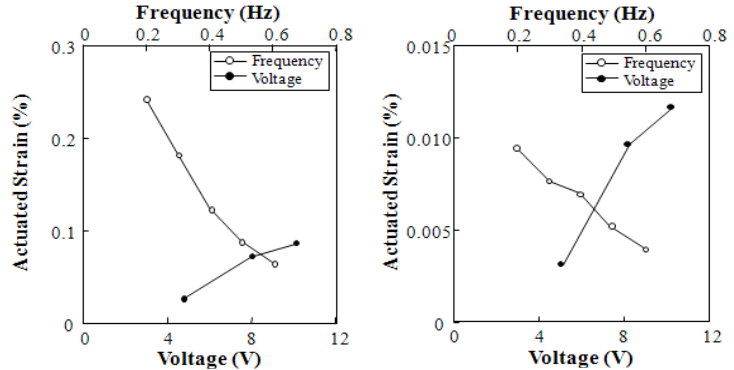

Fig. 9 Actuated strain versus frequency and voltage curve for different actuator, (a) CNT-PVDF and (b) ITO-PVDF layers.

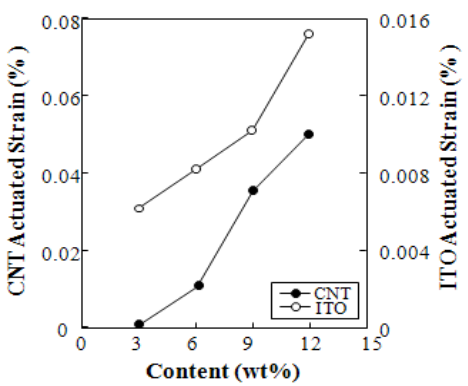

Fig. 10 Actuated strain curve with increasing CNT and ITO, CNT-PVDF and ITO-PVDF layers.

두 물질간의 접착이 강해지며, 접착일이 증가함을 의미한다. 친수성을 보여주는 ITO에 비하여 동일한 소수성을 지니는 $\mathrm{CNT}$ 와 $\mathrm{PVDF}$ 간의 접착일 이 더 큰 값을 보여주었다. 즉, ITO 가 $\mathrm{PVDF}$ 내에 퍼질 때 퍼짐이 잘 되지 않아 퍼짐계수가 작은 반면 상대적으로 $\mathrm{CNT}$ 가 $\mathrm{PVDF}$ 에 퍼짐이 잘 되어 퍼짐계수가 크다. 또한, ITO보다 $\mathrm{CNT}$ 가 $\mathrm{PVDF}$ 내에 잘 퍼지기 때문에 나 노재료와 기지간의 계면에서의 접착일이 큼을 알 수 있다. 접 착일과 퍼짐계수가 같은 경향임을 확인하였다.

\section{3 전기화학적 환경에서 CNT 및 ITO 나노복합재료 작동기의 구동}

Fig. 7은 $10 \mathrm{wt} \%$ 의 CNT와 ITO 나노복합재료의 사인 함 수를 이용한 $0.5 \mathrm{~Hz}$ 와 $10 \mathrm{~V}$ 의 전기화학적인 환경하에서 작 동기의 구동을 보여준다. $\mathrm{CNT}$ 나노복합재료 작동기는 연신 율이 안정되게 나오는 반면, ITO 나노복합재료 작동기는 점 차 상승하는 모양을 보인다. 이는 $\mathrm{CNT}$ 나노복합재료가 ITO 나노복합재료보다 안정적임을 의미한다.

Fig. 8은 구동에 따른 작동기의 표면변화를 도식하였다. 취성을 지니는 ITO 나노복합재료 작동기는 연신이 됨에 따 라 ITO들간에 미세 균열이 발생하여 계면 결착이 불완전하 여 전기저항이 점차적으로 상승하는 모양을 나타내는 것으로 생각된다. 반면, $\mathrm{CNT}$ 들간의 상호 엉킴으로 인하여 구동 변 형에 유연하게 대응하기 때문 에 연신율의 변화가 없다고 사 료된다. 즉, 작동기 연신율의 차이는 각 $\mathrm{CNT}$ 와 ITO 나노재 
료 간의 고유 특성 때문이다.

Fig. 9는 전압과 주파수의 변화에 따른 CNT와 ITO 나노 복합재료의 작동기 연신율을 보여준다. 전압이나노복합재료 의 작동기 연신율을 보여준다. 전압이 증가함에 따라 작동기 연신율은 증가하였으며, 이에 비해, 주파수가 증가함에 따라 작동기 연신율은 감소함을 보여주었다. 두 CNT, ITO 나노복 합재료의 전압과 주파수에 따른 작동기 연신율은 유사한 경 향을 보여주었다. 주파수가 증가함에 따라 작동기 연신율이 감소하는 이유는, 주파수를 증가시키면 작동기가 움직일 수 있는 에너지에 비해, 원래 유발된 연신율 만큼 가지 못한 상 태에서 다시 반대 방향으로 작동이 되기 때문에 연신율이 점 차 줄어든다고 생각된다.

Fig. 10은 CNT와 ITO 나노복합재료의 CNT, ITO 분율에 따른 작동기 연신율을 나타낸다. CNT와 ITO의 분율이 높아 질수록 전기적 전도성도 따라서 커지기 때문에 작동기의 연신 율도 지속적으로 증가함을 알 수 있다. CNT 나노복합재료와 ITO 나노복합재료의 작동기 연신율 값을 보았을 때 동일한 경향을 나타낸다. 하지만, CNT 나노복합재료가 ITO 나노복합 재료보다 작동기 연신율 값이 전반적으로 더 크다는 것을 볼 수 있었다. 결과적으로, 작동기 성능은 전도성 물질인 $\mathrm{CNT}$ 와 $\mathrm{ITO}$ 의 고유 전도성과 연관이 크므로 움직임이 큰 $\mathrm{CNT}$ 나노 복합재료가 보다 더 작동기로 적합하다고 생각된다.

\section{4. 결 론}

$\mathrm{CNT}$ 및 $\mathrm{ITO} / \mathrm{PVDF}$ 나노복합재료의 자체감지능, 계면 젖 음성, 그리고 전기화학적 환경에서 작동기로서의 여러 가지 특성을 평가하였다. 나노복합재료의 전기적 특성과 내구성은 반복하중에 따라 전기저항도로써 두 복합재료의 자체감지능 을 측정 할 수 있었다. CNT-PVDF가 ITO-PVDF 나노복합재 료보다 전기 저항도가 작음을 확인하였다. 나노복합재료의 계면내구성은 $\mathrm{PVDF}$ 와 두 나노복합재료의 각 표면에 접촉각 을 측정함으로서 표면에너지, 그리고 접착일과 퍼짐계수를 측정하였다. ITO의 표면에너지가 높고, 친수성이기 때문에 $\mathrm{ITO}$ 와 고분자간의 큰 접착일을 보여 주었다. 나노복합재료의 작동기 특성은 $\mathrm{CNT}$ 나노복합재료와 ITO 나노복합재료는 감 지능뿐만 아니라 작동기로서 전기화학적 환경하에서 잘 반응 하였다. CNT/PVDF가 ITO/PVDF 나노복합재료보다 크고 안 정한 작동 연신율을 보였다. 이는 $\mathrm{CNT} / \mathrm{PVDF}$ 가 $\mathrm{ITO} / \mathrm{PVDF}$ 보다 큰 고유 전기전도성과 나노 구조네트워크가 좀 더 유연 하기 때문이다. 전압의 증가에 따라 연신율이 증가하며, 그 반면에 주파수가 증가함에 따라 연신율이 감소함을 보였다. $\mathrm{CNT}$ 와 ITO의 함량이 증가 할수록 연신율이 증가함을 보여 주었다. 본 연구의 주요 결과로, $\mathrm{CNT} / \mathrm{PVDF}$ 가 $\mathrm{ITO} / \mathrm{PVDF}$ 보
다 작동기로서 보다 바람직하다는 것을 확인하였다.

\section{감사의 글}

이 연구는 2011년 한국연구재단 기본연구 이공분야 기초 연구과제 지원사업 (KRF-2009-0072538)의 지원을 받아 수행 하였습니다. 본 연구자 중 구가영은 2 단계 $\mathrm{BK} 21$ 의 지원에 감사드립니다.

\section{참고문헌}

1) Bar-Cohen, Y., Xue, T., Shahinpoor, M., Simpson, J.O., and Smith, J., "Flexible, Low-mass Robotic Arm Actuated by Electroactive Polymers," Proceedings of SPIE's 5th Annual International Symposium on Smart Structures and Materials, No. 3329-07, 1998, pp. 1-6.

2) Yang, L., Setyowati, K., Li, A., Gong, S., and Chen, J., "Reversible Infrared Actuation of Carbon Nanotube-Liquid Crystalline Elastomer Nanocomposites," Advanced Materials, Vol. 20, 2008, pp. 2271-2275.

3) 김홍일, 김대관, 한재흥, "IPMC 작동기의 기계적 물성에 관한 연구," 한국복합재료학회지, 제 20 권 제 3 호, $2007, \mathrm{pp.}$ 50-54.

4) 최범규, 이우훈, “압전 필름의 압전정 효과를 이용한 에너지 저장 시스템에 관한 연구," 한국정밀공학회지, 제 25 권 제9 호, 2008, pp. 78-85.

5) Thostenson, E.T., Ren, Z., and Chou, T.W., "Advances in The Science and Technology of Carbon Nanotubes and Their Composites: A Review," Composites Science and Technology, Vol. 61, 2001, pp. 1899-912.

6) Che, J., Cagin, T., and Goddard, W.A., "Thermal Conductivity of Carbon Nanotubes", Nanotechnology, Vol. 11, No. 2, 2000, pp. 65-73.

7) Dilsiz, N., and Wightman, J.P., "Effect of Acid-Base Properties of Unsized and Sized Carbon Fibers on Fiber/Epoxy Matrix Adhesion," Colloids and surfaces A, Vol. 164, 2000, pp. 325-336.

8) Park, J.M., Son, T.Q., Jung, J.G., and Hwang, B.S., "Interfacial Evaluation of Single Ramie and Kenaf Fiber/Epoxy Resin Composites using Micromechanical Test and Nondestructive Acoustic Emission," Composite Interfaces, Vol. 13, No. 2-3, 2006, pp. 105-129.

9) Kinloch, A.J., Adhesion and Adhesives, Chapman and Hall, London 1987, pp. 18-51. 